\title{
RADIOCARBON DATING OF MORTARS FROM THE BAPTISMAL FONT OF THE SAN LORENZO CATHEDRAL OF ALBA (CUNEO, ITALY): COMPARISON WITH THERMOLUMINESCENCE DATING OF RELATED BRICKS AND PIPES
}

\author{
Giovanni L Pesce ${ }^{1,4} \bullet$ Egle Micheletto $^{2} \bullet{\text { Gianluca } \text { Quarta }^{3} \bullet \text { Sofia Uggè }^{2} \text { • Lucio Calcagnile }}^{3}$ • \\ Anna Decri ${ }^{4}$ \\ ABSTRACT. The San Lorenzo Cathedral of Alba is a Romanesque church (rebuilt in Gothic epoch) located in northwest \\ Italy. Since 2007, this church has been subjected to renovations and archaeological excavations that led to the finding of the \\ lower part of the basin and the water drainage pipe of a baptismal font of unknown age. Thermoluminescence and radiocarbon \\ dating have been carried out respectively on some ceramic elements and lime mortar samples used in both the pipe and basin \\ of the font. Thermoluminescence results suggest that some of the bricks may have been reused from previous structures while \\ ${ }^{14} \mathrm{C}$ results suggest that the font was built between the 9th and the 11th centuries $\mathrm{AD}$, most probably in the 10th century AD.
}

\section{INTRODUCTION}

The San Lorenzo Cathedral of Alba is a Romanesque church located in Alba (Cuneo, Piedmont) in northwest Italy. The church was built on the site of a former structure, probably found in the 6th century AD and almost totally rebuilt during the high Middle Ages. Currently, it has a Latin cross with 3 naves in a late Gothic architectural style (Micheletto 2013).

Since 2007, the church has been undergoing renovation and archaeological excavations that have unearthed the remains of an octagonal baptismal font, which had remained in use until the late 12th century. This is located in the southern nave of the existing cathedral where other remains of the Romanesque cathedral are located (Figures 1 and 2). The archaeological excavation, in particular, revealed the lower part of the font and the related water drainage pipe (Subbrizio 2013; Uggé 2013).

The structure lies on a surface of about $3 \mathrm{~m}^{2}$; each side of the octagon is about $110 \mathrm{~cm}$ wide. The structure was built using bricks, stones, and lime mortar. The bricks have been laid on very thin layers of mortar, well-refined when the lime was still wet. At the edges of the octagon, some specifically cut bricks have been used for connecting the faces of the octagon (Figure 2). The internal part of the baptismal font has an elliptical monolithic basin of red Verona marble approximately $137 \mathrm{~cm}$ long (semi-major axis), $100 \mathrm{~cm}$ wide (semi-minor axis), and $40 \mathrm{~cm}$ deep, surrounded by appropriately sized marble slabs. It is likely that the basin was part of an earlier Roman structure. A hydraulic plaster (the so-called cocciopesto) made from air lime and brick powder is used in the mortar joints, in the internal part of the basin.

The majority of bricks used in the font have sizes comparable with those of the Roman age: the bricks are $7 \mathrm{~cm}$ thick, $44 \mathrm{~cm}$ long and with a width that reproduces the size of the so-called sesquipedales, a Roman modulus. Despite this clear identification of the bricks' age, the external faces of several bricks are carved with a special pattern called en-chevron that was widespread in the 10th century (Figure 3).

\footnotetext{
${ }^{1}$ BRE-CICM, Department of Architecture and Civil Engineering, University of Bath, Claverton Campus, Bath, United Kingdom. Corresponding author. Email: G.L.A.Pesce@bath.ac.uk.

${ }^{2}$ Superintendence for the Archaeological Heritage of Piedmont and of MAE, Piazza S. Giovanni, 2, 10122 Turin, Italy. ${ }^{3}$ CEDAD (Centre for Dating and Diagnostic), Department of Engineering for Innovation, University of Salento, via per Monteroni, 73100, Lecce, Italy.

${ }^{4}$ Ipsilon p.s.c.r.l., Via Martin Piaggio 13/9A, 16121, Genoa, Italy.
}

(c) 2013 by the Arizona Board of Regents on behalf of the University of Arizona Proceedings of the 21st International Radiocarbon Conference edited by A J T Jull \& C Hatté RADIOCARBON, Vol 55, Nr 2-3, 2013, p 526-533 


\section{G L Pesce et al.}

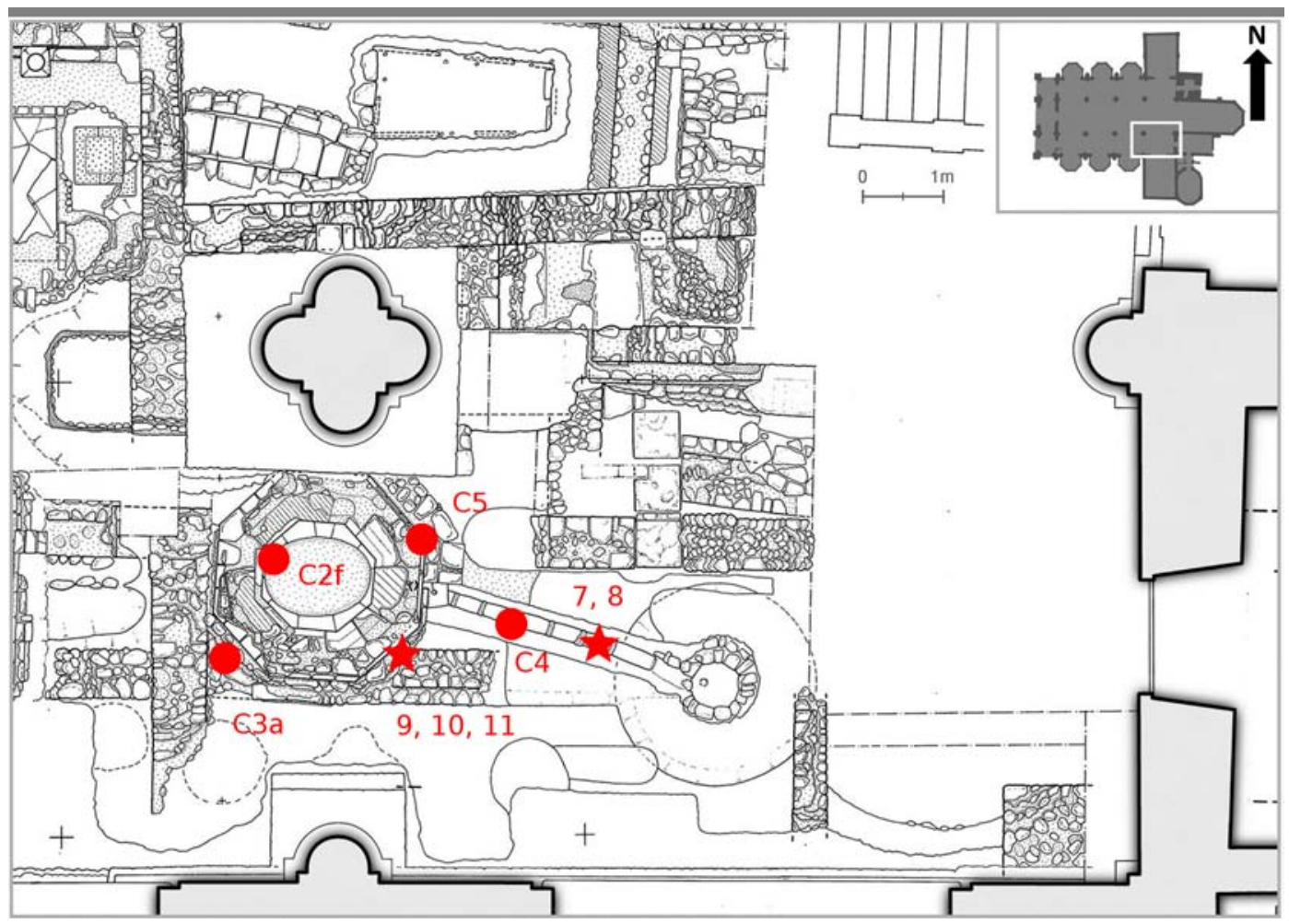

Figure 1 San Lorenzo Cathedral of Alba (Cuneo, Italy). Survey of the baptismal font with the drainage pipe (Archive of the Superintendence for the Archaeological Heritage of del Piedmont and of MAE). Circles indicate the position of lime lumps while the star-shaped symbols indicate the location of the brick samples (samples 13, 22, 23, and 24 were taken in structures not included in this survey).

In contrast, bricks used in other structures recovered during the same excavations, such as a perimeter wall (USM 993) and the external side of the bell tower, were characterized by sizes more similar to the Medieval modulus used since the 12th century AD: approximately $7 \mathrm{~cm}$ thick, $14 \mathrm{~cm}$ wide, and $30 \mathrm{~cm}$ long (Greppi 2013).

Due to the inconsistency of these characteristics and because of the reduced volume of the remains, it was not possible to determine when the font was built nor whether it was built in a single phase or more phases (e.g. if the font was modified during the time before the complete destruction). For these reasons, archaeometric dating was required. According to the archaeological record, the font was supposed to be built between the end of the 6th century and the second half of the 12th century (Table 1), when the basin was filled with rubble. In fact, due to a change in the baptismal ceremony and, consequently, to a change in the shape of the baptismal fonts, in the second half of the 12th century, the structure was partially filled with rubble and modified according to the new needs (the full immersion of the body was abandoned and, consequently, the baptismal fonts that previously originated from the ground were built with a basin lifted from the ground; Uggé 2013). Among the other modifications a new drainage pipe was also built without destroying the original one.

Within the previous mentioned time range (6th-12th century AD), according to the en-chevron pattern carved on the surfaces of the bricks, archaeologists estimate that the font could have been built during the 10th century AD, but no other proof of this hypothesis was given. 


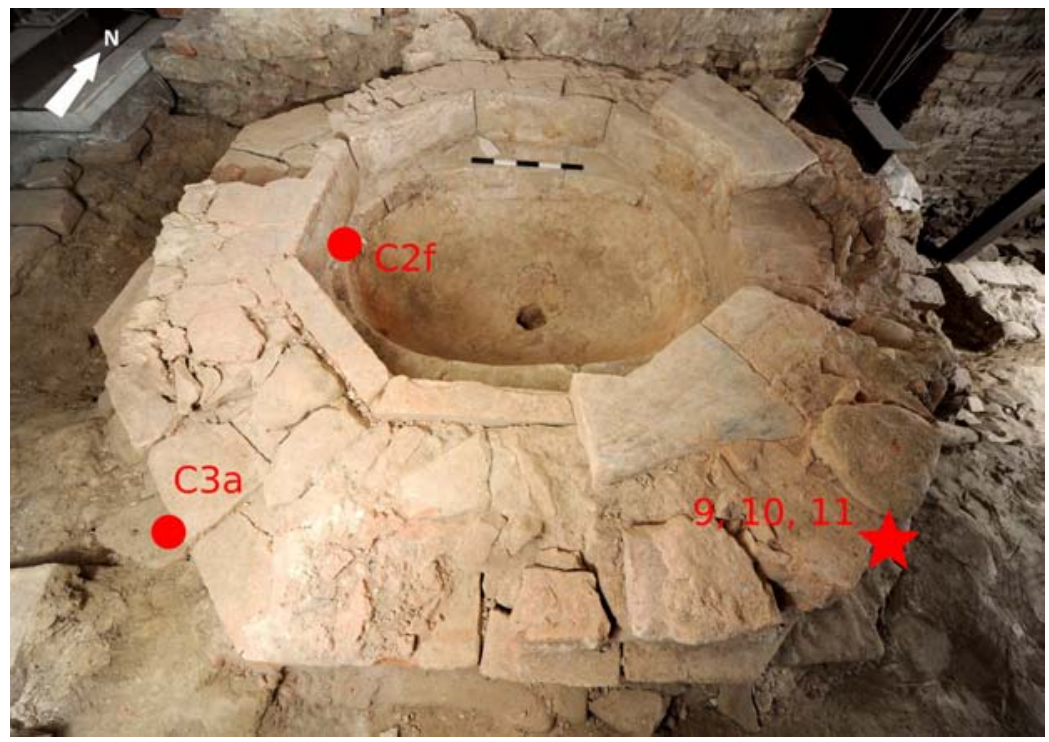

Figure 2 Image of the remains of the baptismal font (Archive of the Superintendence for the Archaeological Heritage of del Piedmont and of MAE). Dots indicate the position of some of the lime lumps while the star-shaped symbols indicate the location of some of the brick samples.

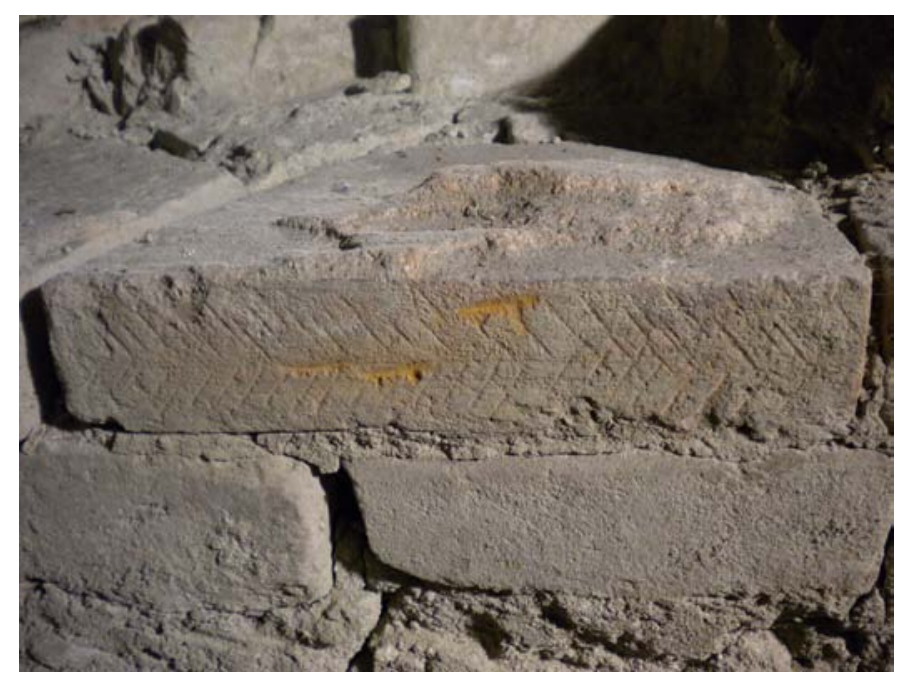

Figure 3 Octagonal perimeter of the baptismal font: detail of the special pattern called en-chevron scratched on the surface of some bricks (Archive of the Superintendence for the Archaeological Heritage of del Piedmont and of MAE).

\section{MATERIALS AND METHODS}

Considering the available materials, the radiocarbon dating method was chosen to date the lime mortar used in the font, and the thermoluminescence (TL) method was chosen to verify the dating of bricks and pipes. For ${ }^{14} \mathrm{C}$ dating, lumps of pure lime were extracted from many samples taken from the mortar used in different parts of the font and dated with the "pure lime lumps" technique 


\section{G L Pesce et al.}

(Pesce and Ball 2012); no organic samples were found. Each mortar sample was no more than a few cubic $\mathrm{cm}$. Table 1 lists the weights of the dated lumps.

Table 1 Radiocarbon dating results.

\begin{tabular}{lclllll}
\hline $\begin{array}{l}\text { Speci- } \\
\text { men }\end{array}$ & $\begin{array}{l}\text { Weight } \\
(\mathrm{mg})\end{array}$ & $\begin{array}{l}\text { CEDAD } \\
\text { code }\end{array}$ & $\begin{array}{l}\text { Uncali- } \\
\text { brated } \\
\text { ages (BP) }\end{array}$ & $\begin{array}{l}\text { Calibrated } \\
\text { ages } \\
\text { (cal AD) }\end{array}$ & $\begin{array}{l}\text { Probability } \\
\text { (partial } \\
\text { data) }\end{array}$ & Supposed age \\
\hline C2f & 33 & LTL8445A & $1121 \pm 45$ & $\begin{array}{l}780-790 \\
800-1020\end{array}$ & $\begin{array}{l}1.9 \% \\
93.5 \%\end{array}$ & From end of 6th to end of 10th century AD \\
C3a & 109 & LTL8287A & $1142 \pm 40$ & $\begin{array}{l}770-990 \\
95.4 \%\end{array}$ & End of 6th century AD? \\
C4 & 86 & LTL8288A & $1188 \pm 50$ & $\begin{array}{l}760-980 \\
690-750\end{array}$ & $\begin{array}{l}83.7 \% \\
11.7 \%\end{array}$ & From end of 6th to end of 12th century AD \\
C5 & 31 & LTL8289A & $1141 \pm 40$ & $770-990$ & $95.4 \%$ & No later than the end of 12th century AD \\
\hline
\end{tabular}

The principle underlying the "pure lime lumps" technique is the use of pure lime lumps (often embedded in old lime mortar) opposed to generic pieces of mortar (bulk samples). Because these lumps contain the same lime of the mixture and are free of contaminants such as grains of limestone sand, we expect they can dramatically reduce errors in ${ }^{14} \mathrm{C}$ dating. The carbonation of lime contained in the lumps located very close to the surfaces of the structures is reasonably expected to be the same as the construction and, consequently, carbon contained in the lime lumps should reflect the atmospheric ${ }^{14} \mathrm{C}$ concentration at the time of hardening (Pesce et al. 2009, 2012).

Specimens were sampled in the mortar that binds the stones of the basin rim (C2f), in the foundation (C3a), in the mortar used beneath the original drainage pipe (C4), and in the mortar used among the bricks with the en-chevron pattern (C5). Sampling points (reported in Figures 1 and 2) were arranged with the Superintendence for the Archaeological Heritage of Piedmont and were chosen to be as close to the surface structures as possible in order to reduce the delay of carbonation. Moreover, because of the continued presence of water in the structure (the baptismal font contained water during its use), specimens that clearly contained reprecipitated calcium carbonate were carefully avoided.

Before the removal of the lime lumps from the mortar samples, each specimen was analyzed by a geologist, Roberto Ricci (freelancer), in order to obtain the mineralogical characteristics of the mixes and origin of aggregates, which is useful to evaluate possible differences among the specimens and, consequently, to evaluate the ${ }^{14} \mathrm{C}$ dating results. Analyses were carried out at low magnification, using a Nikon SZM 800 stereomicroscope and a fiberoptic illuminator on the specimens as they were taken from the archaeological site (i.e. without preparation).

Results of the analyses showed that the mixture of the sample C2f contained air lime as the main binder phase and brick powder (cocciopesto) as a hydraulic additive. The sand, which had a poor particle size distribution, was taken from the Po River (mainly composed of quartz) with a maximum grain size of $1 \mathrm{~mm}$. Several tiny lumps of pure lime were found inside the mixture. Mortar of the samples C3, C4, and C5 contained air lime as the binder and sand with a poor particle size distribution as aggregate, once again taken from the Po River. A high aggregate:binder ratio was observed as the maximum size of the grains that were evaluated was about $1 \mathrm{~mm}$. Several pure lime lumps of a few $\mathrm{mm}$ in diameter were found during the analysis.

Subsequently, the specimens were analyzed at the University of Bath (UK) with a Leica Wild M3 stereomicroscope for identification and removal of the pure lime lumps according to the technique described in Pesce and Ball (2012). Once isolated, the lumps were submitted for AMS ${ }^{14} \mathrm{C}$ dating at the Centre for Dating and Diagnostic, University of Salento (Lecce, Italy; Calcagnile et al. 2005). 
${ }^{14} \mathrm{C}$ Dating of Mortars from the Baptismal Font

The samples underwent the standard procedure used for carbonates consisting of a mechanical cleaning with tweezers and scalpel under the lenses of an optical microscope, for the removal of the last visible macrocontaminants set on the surface. This analysis was followed by a treatment with $30 \% \mathrm{H}_{2} \mathrm{O}_{2}$ in an ultrasonic bath to eliminate the external layer of the sample. For each specimen, between 8 and $10 \mathrm{mg}$ of the precleaned lump was dried in an oven at $60^{\circ} \mathrm{C}$ for $8 \mathrm{hr}$, then treated with ultra-high-purity $15 \% \mathrm{H}_{2} \mathrm{O}_{2}$, and then converted to $\mathrm{CO}_{2}$ in quartz ampoules using $\mathrm{H}_{3} \mathrm{PO}_{4}$, according to the description reported in Pesce et al. (2009). Finally, the graphite obtained was pressed in the target holders of the accelerator mass spectrometer for measurement of the carbon isotopic ratios. An International Atomic Energy Agency (IAEA) C6 sucrose standard with a nominal ${ }^{14} \mathrm{C}$ concentration of $150.61 \mathrm{pMC}$ and C1 Carrara marble with a nominal ${ }^{14} \mathrm{C}$ content of $0 \mathrm{pMC}$ were used as standards for normalization and for estimation of the measurement and sample processing background, respectively (Pesce et al. 2009). OxCal v 3.10 software (Bronk Ramsey 2009) and the IntCal09 curve (Reimer et al. 2009) were used for calibration of the ${ }^{14} \mathrm{C}$ dates.

To determine the production time of the bricks, some specimens (made of up to 3 pieces each) were taken and sent to the laboratory for TL dating. To verify differences in size and age, 9 samples including bricks and ceramic parts of the old pipe were taken from the baptismal font and from other structures. In particular, specimens 7 and 8 (pipes) were taken from different parts of the drainage pipe of the baptismal font; specimens 9, 10, and 11 (bricks) from the foundation of the baptismal font; specimens 12 and 13 (bricks) from the wall US 993; and specimens 22-24 (bricks) in the external wall of the bell tower. The last 3 specimens, in particular, were characterized by the Medieval modulus and, consequently, could have been used to evaluate the results of the TL dating method applied to the bricks.

TL dating was carried out at the Dating Centre of the Laboratory of Archaeometry of the University Milano Bicocca (Milan, Italy) using the fine-grain technique. Evaluation of the annual dose was performed using measurements of total alpha activity (contribution of uranium and thorium) and a flame photometric detector (contribution of potassium) on the ceramic objects. Contribution of environmental dose range was measured with the ionization chamber for the environmental dosimeter. A water content of $80 \pm 20 \%$ of the saturation value was used for the data processing. Detailed information on TL dating of these bricks is reported in Sibilia (2010).

\section{RESULTS AND DISCUSSION}

The ${ }^{14} \mathrm{C}$ dates of the mortars are reported in Figure 4 and summarized in Table 1 . Figure 5 presents a graphical comparison of the results obtained with both dating methods. The results show that the calibrated ${ }^{14} \mathrm{C}$ dates are consistent with each other and fell between cal AD 690 and 1020.

The consistency of the results suggests that a delay in the carbonation time due to a delay in the penetration of carbon dioxide inside the mortars is unlikely, as well as the effect of a dissolution and reprecipitation process of calcium carbonate due to the groundwater or to the water originally contained in the font. In fact, even if one of these factors had taken place, the probability that the ${ }^{14} \mathrm{C}$ dating of the samples were so similar would have been extremely rare, considering the locations of the samples.

Results of the TL dating are reported in Table 2. According to these results, specimens 7, 8, 9, 10, and 11 are contemporaneous and dated to the 6th century AD (Table 2). Different results were found for specimen 13 (11th century AD; specimen 12 did not give results) and for specimens 22-24 (second half of the 8th century AD to first half of the 9th century AD). 


\section{G L Pesce et al.}

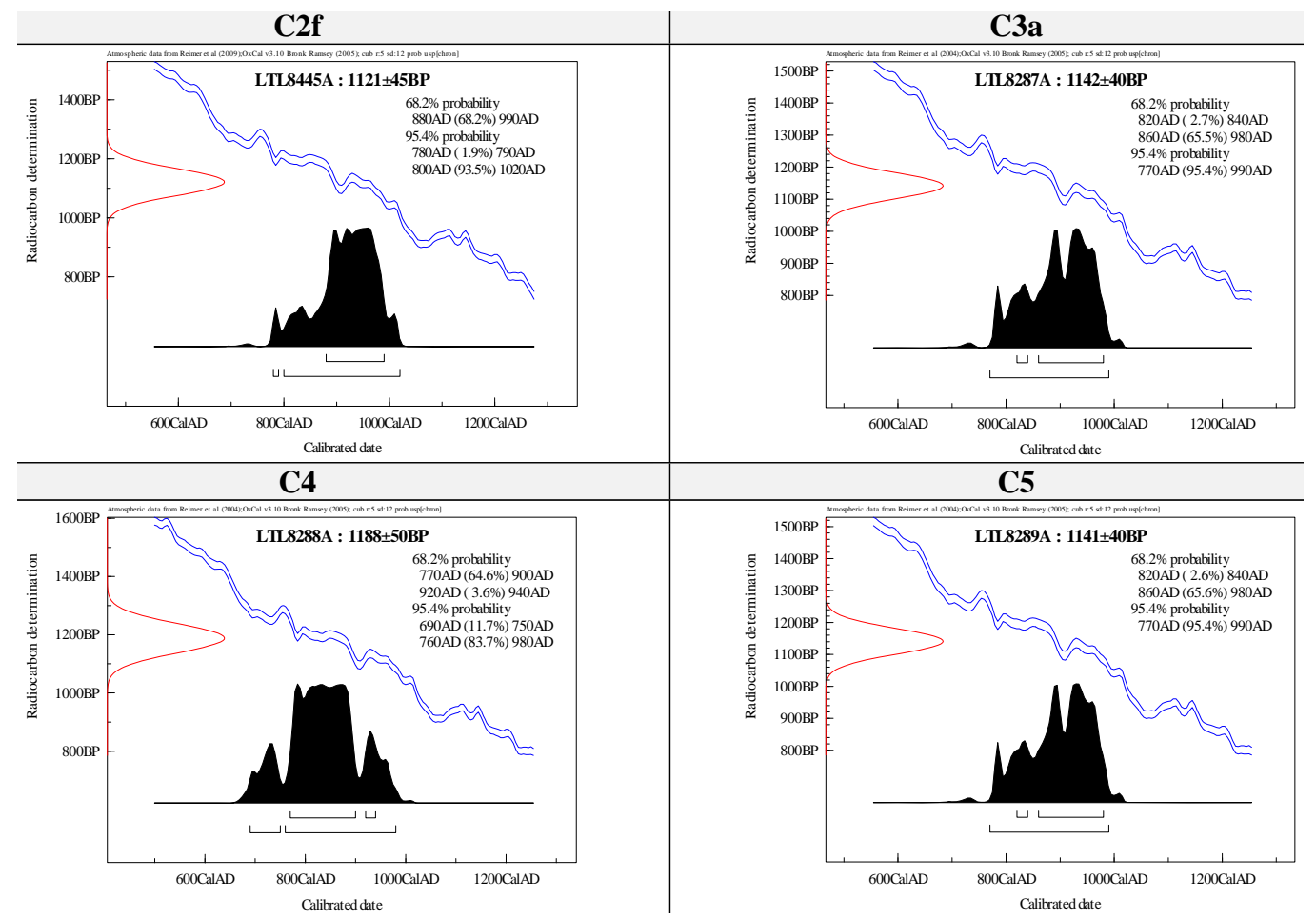

Figure $4{ }^{14} \mathrm{C}$ dating results of the pure lime lumps collected in the baptismal font

$=\mathrm{TL}(95,4 \%+68,2 \%)$
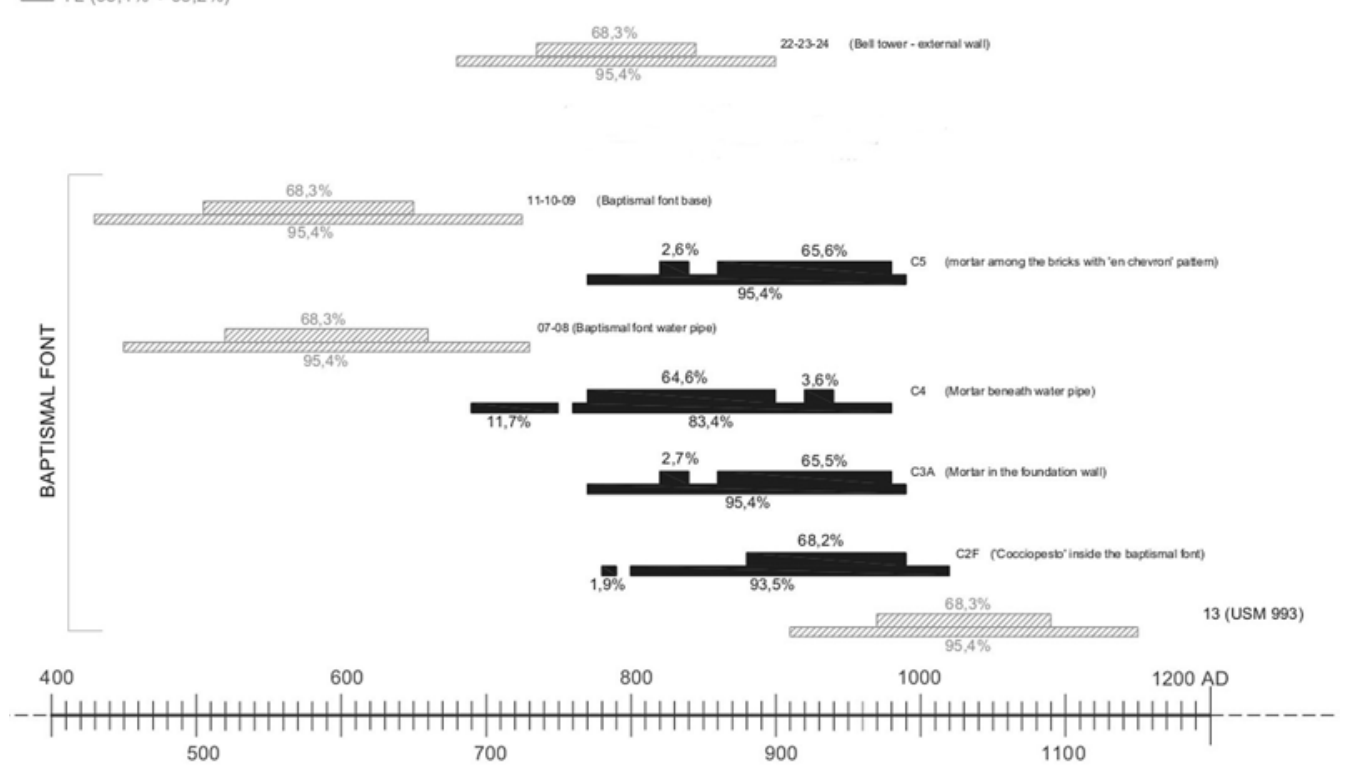

Figure 5 Graphical description of the calibrated ${ }^{14} \mathrm{C}$ dating (black lines) and of dating of bricks obtained with the thermoluminescence method (hatched lines). 
${ }^{14} \mathrm{C}$ Dating of Mortars from the Baptismal Font

Considering the brick dimensions and the obtained results, it is possible to note a correspondence between the bricks with Roman sizes and the TL date: according to the TL results, the bricks with a Roman modulus are actually connected with the late Roman tradition, whereas those with Medieval modulus have been found to be produced later.

Table 2 Results of thermoluminescence datinga.

\begin{tabular}{|c|c|c|c|c|}
\hline Samples ${ }^{\mathrm{b}}$ & Location & $\begin{array}{l}\text { Date } \\
\text { (AD) }\end{array}$ & $\begin{array}{l}\text { Average date } \\
\text { (AD) }\end{array}$ & Supposed age \\
\hline 7 & Drainage pipe & $580 \pm 80$ & $590 \pm 70$ & Roman age \\
\hline 8 & Drainage pipe & $595 \pm 100$ & & Roman age \\
\hline 9 & Foundation of the baptismal font & $595 \pm 65$ & $575 \pm 75$ & Roman age \\
\hline 10 & Foundation of the baptismal font & $595 \pm 65$ & & Roman age \\
\hline 11 & Foundation of the baptismal font & $600 \pm 100$ & & Roman age \\
\hline 13 & USM 993 & $1030 \pm 60$ & $1030 \pm 60$ & Medieval age \\
\hline 22 & Bell tower, external & $810 \pm 70$ & $790 \pm 55$ & Medieval age \\
\hline 23 & Bell tower, external & $790 \pm 95$ & & Medieval age \\
\hline 24 & Bell tower, external & $825 \pm 60$ & & Medieval age \\
\hline
\end{tabular}

${ }^{a}$ Confidence interval $1 \sigma$; results of dating and methodology from Sibilia (2010).

bSample \#12 not available.

The TL dates of samples 7, 8, 9, 10, and 11 differ from the ${ }^{14} \mathrm{C}$ dates of the lime lumps; therefore, it is probable that the pipe and the bricks are older than the lime mortar binding them and likely could have been reused. As discussed previously, because a delay of $\sim 2$ centuries in the carbonation seems unlikely and because the ${ }^{14} \mathrm{C}$ dating of mortars is in agreement with the dating of the en-chevron pattern, it is likely that the ceramic elements used in the baptismal font could have been actually reused from previous structures (or that an earlier structure could have been adapted later to the use as baptismal font). The reuse of bricks from earlier structures was a very common practice in past centuries, as already witnessed inside the cathedral itself and in many other places in northern Italy.

This result is confirmed by TL dating of the bricks used in the external wall of the bell tower (specimens 22-24) and in sample US 993. These bricks, in fact, have been dated to a time very similar to that of the lime lumps, and their dimensions agree with the dimension of the Medieval modulus.

\section{CONCLUSIONS}

The consistency of the ${ }^{14} \mathrm{C}$ dating results and the results obtained from the mineralogical analyses of the mortar, as well as the small size of the structure, suggest that the baptismal font of the Alba Cathedral was built in a single constructive phase between AD 770 and 990. Thermoluminescence dating suggests that the ceramic materials (bricks and pipes) used in the baptismal font were produced between AD 500 and 650 and therefore were reused later in the baptismal font. At the time if their reuse, the en-chevron pattern was carved according to a practice that, from an archaeological point of view, is typical of the 10th century. For these reasons and considering the archaeological and historic record, it is possible to hypothesize that within the above-mentioned range of time (cal AD 770-990), the most probable construction time of the baptismal font is the end of the 10th century AD.

\section{REFERENCES}

Bronk Ramsey C. 2009. Bayesian analysis of radiocarbon dates. Radiocarbon 51(1):337-60.
Calcagnile L, Quarta G, D’Elia M. 2005. High-resolution accelerator-based mass spectrometry: precision, accu- 


\section{G L Pesce et al.}

racy and background. Applied Radiation and Isotopes 62(4):623-9.

Greppi P. 2013. Murature Medievali in laterizi. In: Micheletto E, editor. La Cattedrale di Alba. Archeologia di un cantiere. Florence: All'Insegna del Giglio. p 107-14.

Micheletto E, editor. 2013. La Cattedrale di Alba. Archeologia di un cantiere. Florence: All'Insegna del Giglio.

Pesce GLA, Ball RJ. 2012. Dating of Old Lime Based Mixtures with the "Pure Lime Lumps" Technique. In: Michalska Nawrocka D, editor. Radiometric Dating. InTech. p 21-38. URL: http://www.intechopen.com/ articles/show/title/dating-of-old-lime-based-mixtures-with-the-pure-lime-lumps-technique. doi: 10.5772/35419. Accessed 27 April 2013.

Pesce GLA, Quarta G, Calcagnile L, D’Elia M, Cavaciocchi P, Lastrico C, Guastella R. 2009. Radiocarbon dating of lumps from aerial lime mortars and plasters: methodological issues and results from San Nicolò of Capodimonte church (Camogli, Genoa, Italy). Radiocarbon 51(2):867-72.

Pesce GLA, Ball R, Quarta G, Calcagnile L. 2012. Identification, extraction, and preparation of reliable samples for ${ }^{14} \mathrm{C}$ dating of plasters and mortars with the "pure lime lumps" technique. Radiocarbon 54(3-4): 933-42.

Reimer PJ, Baillie MGL, Bard E, Bayliss A, Beck JW, Blackwell PG, Bronk Ramsey C, Buck CE, Burr GS, Edwards RL, Friedrich M, Grootes PM, Guilderson TP, Hajdas I, Heaton T, Hogg AG, Hughen KA, Kaiser KF, Kromer B, McCormac FG, Manning SW, Reimer RW, Richards DA, Southon JR, Talamo S, Turney CSM, van der Plicht J, Weyhenmeyer CE. 2009. IntCal09 and Marine09 radiocarbon age calibration curves, 0-50,000 years cal BP. Radiocarbon 51(4): 1111-50.

Sibilia E. 2010. Analisi di termoluminescenza (TL), Cattedrale di Alba. Milan: Dating Centre of the University Milano Bicocca, Laboratory of Archaeometry.

Subbrizio M. 2013. Lo scavo archeologico. In: Micheletto E, editor. La Cattedrale di Alba. Archeologia di un cantiere. Florence: All'Insegna del Giglio. p 123-65.

Uggé S. 2013. Il fonte battesimale. In: Micheletto E, editor. La Cattedrale di Alba. Archeologia di un cantiere. Florence: All’Insegna del Giglio. p 83-93. 